Columbia Law School

Scholarship Archive

2003

\title{
From Violent Crime to Terrorism: The Changing Basis of the Federal, State and Local Law Enforcement Dynamic
}

Daniel C. Richman

Columbia Law School, drichm@law.columbia.edu

Follow this and additional works at: https://scholarship.law.columbia.edu/faculty_scholarship

Part of the Criminal Law Commons, Law Enforcement and Corrections Commons, and the National Security Law Commons

\section{Recommended Citation}

Daniel C. Richman, From Violent Crime to Terrorism: The Changing Basis of the Federal, State and Local Law Enforcement Dynamic, Fordham School of LaW Public LaW Research PaPer No. 31 (2003).

Available at: https://scholarship.law.columbia.edu/faculty_scholarship/1297

This Working Paper is brought to you for free and open access by the Faculty Publications at Scholarship Archive. It has been accepted for inclusion in Faculty Scholarship by an authorized administrator of Scholarship Archive. For more information, please contact scholarshiparchive@law.columbia.edu. 


\title{
Fordham University School of Law
}

\author{
Public Law and Legal Theory \\ Research Paper No. 31
}

\section{From Violent Crime to Terrorism: The Changing Basis of the Federal, State and Local Law Enforcement Dynamic}

\section{Daniel C. Richman Professor of Law}




\section{By Daniel Richman*}

Two lines of questions dominate discussions about how the nation ought to respond at home to the new (or rather newly perceived) terrorist threat: How do we ensure that information about potential terrorist activities is effectively gathered, shared, and used? And how do we ensure that the Government neither abuses the investigative authority we give it, nor demands more authority than it needs? (One's priorities and risk assessments may affect the order in which one poses these questions.) The legislative hearings and expert debates on these two issues sound quite different. Understandably so, for each has a distinct conceptual center of gravity. The first sparks aspirations of "connected dots," "broken walls," and eliminated "stovepipes." The second provokes arguments about accountability and the proper balance between individual liberties (broadly, and even extralegally defined).

Each line can profitably be pursued in its own terms. Yet to keep the conversations separate is to miss seeing how the very process of creating an effective domestic intelligence network may introduce a salutary level of accountability and balance in the system. The key lies in the relationships among the local, state, and federal units out of which the network must be created, and their organic characteristics. And the seeds of this promising institutional dynamic can be found in the recent history of the interaction among federal, state, and local governments in the policing area.

\section{The Pre-9/11 Violent Crime Dynamic}

It has long been a truism that, in our federal system, episodic violent crime is the province of state and local authorities. And usually local authorities at that, for very few states have integrated law enforcement hierarchies. It is therefore local police, working with local district attorneys, and county sheriffs, working with county attorneys, who have primary responsibility for keeping the streets and roads safe, and going after rapists, robbers, and murderers.

This responsibility has been enshrined in Supreme Court rulings, ${ }^{1}$ recognized in congressional debates, ${ }^{2}$ and generally understood by federal, state and local enforcers. In

\footnotetext{
* Professor, Fordham Law School; thanks to Bill Stuntz and Dave Sklansky, and to Rick Pildes, Stephen Holmes, and their NYU Center on Law and Security Colloquium for helpful feedback.

${ }^{1}$ See Jones v. United States, 120 S. Ct. 1904,1912 (2000) (reading statute to avoid the constitutional question that would arise were "'traditionally local criminal conduct"” to be made "a matter for federal enforcement'”) (quoting United States v. Bass, 404 U.S. 336, 350 (1971); United States v. Morrison, 120 S. Ct. 1740 (2000); United States v. Lopez, 514 U.S. 549 (1995).

${ }^{2}$ See, e.g. 116 Cong. Rec. 35217 (1970) (remarks of Rep. Eckhardt) (noting concern that RICO statute would "mov[e] large substantive areas formerly totally with the police power of the state into the federal realm”).
} 
the 1960s, however, a long story of federal involvement began. I use the term "involvement," rather than "intervention," to signal my neutrality in this area. As I said before, "it is futile and unnecessary to look for some a priori constitutional divide that [] puts street crime outside federal bounds." ${ }^{3}$ Although, as will be seen, this talk has some important normative aspects, much of the story is strictly positive.

The story starts with Barry Goldwater's acceptance speech at the 1964 Republican convention, when the nominee seized on public crime concerns and made the "violence in our streets" a focus of his presidential campaign. ${ }^{4}$ Goldwater lost big, but in 1965, the Johnson Administration addressed these concerns by establishing the President's Commission on Law Enforcement and the Administration of Justice and by getting passage of the Law Enforcement Assistance Act of 1965. ${ }^{5}$ As Malcolm Feeley and Austin Sarat's valuable study explains, the Office of Law Enforcement Assistance, created to administer the grants authorized by this Act, "legitimized the view that the fed government should provide financial assistance to state and local law enforcement." And thereafter, the President's Commission "proposed that the federal government become an active partner in combating crime at the state and local levels."

The primary activity of this new partner, however, was simply writing checks. For despite all the rhetoric of planning and coordination, that's what the federal government's new role amounted to. ${ }^{8}$ When in 1967, anticipating (quite correctly) that street crime would be a critical issue in the 1968 election, the Johnson Administration sought to create a larger scale grants program, House Republicans successfully demanded that funding be given as block-grants to the states. ${ }^{9}$ And without adequate means to target and monitor expenditures, the new Law Enforcement Assistance Administration ${ }^{10}$ became not a force for crime-policy innovation but simply a way of increasing funding to the status quo.

The LEAA story is usually told as one of policy failure. And that it was, from the perspective of those looking for improved crime policies and reduced crime rates. ${ }^{11}$ But

\footnotetext{
${ }^{3}$ Daniel C. Richman, "Project Exile” and the Allocation of Federal Law Enforcement Authority, 43 Ariz. L. Rev. 369, 404 (2001).

${ }^{4}$ See Malcolm M. Feeley \& Austin D. Sarat, The Policy Dilemma: Federal Crime Policy and the Law Enforcement Assistance Administration 35 (U Minn Press, 1980).

${ }^{5}$ Id. at 36.

${ }^{6}$ Id.

${ }^{7}$ Id. at 38.

${ }^{8}$ See John J. DiIulio, Jr. et al., The Federal Role in Crime Control, in Crime (James Q. Wilson \& Joan Petersilia, eds.) 445, 454 (1995) ("[T]he LEAA was designed and functioned basically as a check-writing machine for channeling federal dollars to state and local govts .").

${ }^{9}$ See Feeley \& Sarat, supra note _ , at 42-46.

${ }^{10}$ The LEAA was established in Omnibus Crime Control \& Safe Streets Act of 1968, Pub. L. 90-351.

${ }^{11}$ See DiIuilio, supra note _ , at 455; Feeley \& Sarat, supra note _ , at _ ; Robert F. Diegelman, Federal Financial Assistance for Crime Control: Lessons of the LEAA Experience, 73 J. Crim. L. \& Criminology 994 (1982).
} 
from the perspective of state and local enforcement agencies eager for federal dollars without federal mandates, the LEAA was surely a success that only improved with time. Its budget kept increasing, at least until 1977. ${ }^{12}$ And the bureaucratic steps that stood between agencies, particularly large police forces, and their money were only reduced. ${ }^{13}$

But the LEAA soon fell out of favor in Washington, attacked by Jimmy Carter for wasting money, and finally phased out by Ronald Reagan in 1982. As Philip Heymann and Mark Moore put it: "[S]tarting in the 1980s, the federal role in financing state and local efforts was de-emphasized in favor of reasserting a direct federal operational role in dealing with crime. LEAA was declared a failure, its name changed, its authorization narrowed, its appropriations slashed, and its bureaucratic status reduced - the public equivalent of a corporate bankruptcy."

Many of the criminal statutes needed to support this "direct federal operational role" were already on the books by 1980: drug trafficking offenses, gun offenses, and racketeering laws. And, in any event, more were soon passed by legislators eager to show their commitment to the Wars on Crime and Drugs. ${ }^{15}$ What really changed in the 1980s, however, was the readiness of the federal government to commit investigative and adjudication resources to street crime, and to pay for the incarceration of convicted offenders.

It is hard fully to quantify the degree to which federal enforcers in the 1980 s moved into what hitherto had been local cases. The number of drug cases certainly climbed. ${ }^{16}$ But that number includes both higher and lower level trafficking offenses. And while, as we increasingly see, ${ }^{17}$ federal weapons charges can be used against street criminals, the large number of federal weapons prosecutions brought during this period ${ }^{18}$ could have had other targets as well. By the 1990s, however, efforts by both the Bush(I) and Clinton administrations to raise the visibility of federal enforcement operations against street criminals made the extent of federal activity quite clear.

\footnotetext{
${ }^{12}$ See Diluilio, supra note _, at 454.

${ }^{13}$ Diegelman, supra note _ , at 998-99 ( in early 1970s: "Congressional tinkering with the [Safe Streets] Act focused on adjustment in the roles of states, major cities, and counties. Statutory and administrative changes gradually attempted to guarantee to the larger jurisdictions a role in planning and decisionmaking in what had been an almost totally state-directed program.”).

${ }^{14}$ Philip B. Heymann \& Mark H. Moore, The Federal Role in Dealing with Violent Street Crime: Principles, Questions, and Cautions, 543 Annals of Amer. Acad. Pol. \& Soc. Sci. 103, 107 (1996).

${ }^{15}$ See Daniel C. Richman, The Changing Boundaries Between Federal and Local Law Enforcment, in 2 Boundary Changes in Criminal Justice Organizations, 108 (Nat'l Inst. of Justice ed., 2000); see also Kathleen F. Brickey, Criminal Mischief: The Federalization of American Criminal Law, 46 Hastings L. J. 1135 (1995).

${ }^{16}$ Bureau of Justice Statistics, Dep't of Justice, Federal Criminal Case Processing, 1982-93, at 2 (May 1996) (number of suspects prosecuted in federal court for drug offenses goes from 9906 in 1982 to 25,094 in 1990), available at http://www.ojp.usdoj.gov/bjs/pub/pdf/fccp93.pdf.

${ }^{17}$ See Richman, Project Exile, supra note _.

${ }^{18}$ Federal Criminal Case Processing, supra note _ , at 2 (number of suspects prosecuted in federal court for weapons offenses goes from 1970 in 1982 to 12,168 in 1990).
} 
The nouns fly fast and furious here. "Project Triggerlock," announced in 1991 by Attorney General Thornburgh, asked U.S. Attorneys to work with local police forces to identify repeat and violent offenders who used guns and to prosecute them in federal court. ${ }^{19}$ In January 1992, the FBI announced its "Safe Street Violent Crimes Initiative," focusing on "violent gangs, crimes of violence, and the apprehension of violent fugitives." ${ }^{20}$ In August 1992, ATF announced "Operation Achilles Heel," and pledged to work with state and local authorities to round up 600 "of this nation's most violent criminals."21 During the summer of 1992, the chief of the Criminal Division in the FBI's New York office told some agents that "terrorism was dead," and tried to move them away from investigating the group later responsible for the 1993 World Trade Center bombing, and into urban gang investigations. ${ }^{22}$ The change in presidential administrations did not significantly alter the trajectory of federal enforcement policy in this area, or the desire to highlight it. In 1994, Vice President Gore and Attorney General Reno announced the Anti-Violent Crime Initiative. And while there was sustained debate on Capitol Hill about the Clinton Administration's approach to gun crimes, the only real issue was whether the federal interest in pursuing these offenses could be served by federally sponsored state prosecutions as well as federal prosecutions (as the Clinton Administration wanted) or whether only federal prosecutions would do (as Republican opponents suggested). ${ }^{23}$ Between 1989 and 1998, the number of federal firearms prosecutions went up 61\%. ${ }^{24}$ And by 2000, the FBI could boast of having deployed Safe Streets Task Forces that included 805 FBI special agents, 251 other federal agents, and 1,096 state and local law enforcement participants (whose overtime the Bureau paid for). ${ }^{25}$

The efforts by the Bush(I) and Clinton administrations to deploy federal agents and prosecutors against violent crime - either on their own or in various joint task forces - did not come at the expense of federal grants to state and local governments in this area. Indeed, both in their dollar amounts and in the discretion they gave to state and local enforcers, federal grant programs took off during the 1990s. The Crime Control Act of $1990^{26}$ authorized $\$ 900$ million for the Edward Byrne Memorial State and Local Law Enforcement Assistance programs - which funded narcotics enforcement and were administered by the states. ${ }^{27}$ With the election of Bill Clinton, and in the wake of his campaign promise to put 100,000 new police officers on the streets came the Violent

\footnotetext{
${ }^{19}$ Project Exile, supra note _, at 374.

${ }^{20}$ FBI, Safe Street Violent Crime Initiative Report, FY 2000, available at http://www.fbi.gov/publications/safestreets/ssgu00.pdf

${ }^{21}$ Project Exile, supra note _ at 375.

${ }^{22}$ John Miller, et al, The Cell: Inside the 9/11 Plot, and Why the FBI and CIA Failed to Stop It 84 (2003).

${ }^{23}$ Project Exile, supra note

${ }^{24}$ Patrick Walker and Pragati Patrick, Admin. Office of the U.S. Courts, Trends in Firearms Cases from Fiscal Year 1989 through 1998, and the Workload Implications for the U.S. District Courts (Apr. 4, 2000), available at http://www.uscourts.gov/firearms/firearms00.html.

${ }^{25}$ See FBI, Street Violent Crime Initiative Report, FY 2000, supra note _, at 2-3.

${ }^{26}$ Pub. L. 101-647.

${ }^{27}$ See Garrine P. Laney, Crime Control Assistance through the Byrne Programs, CRS Report, 97-265 GOV (updated May 20, 1998).
} 
Crime Control and Law Enforcement Act of 1994, ${ }^{28}$ which "authorized the spending of a staggering $\$ 30$ billion to help State and local enforcement agencies fight crime over the 6 -year life of the bill's coverage." 29 The big development here was a readiness - in the form of the COPS ("Community Oriented Police Services") programs to put money directly into the hand of local police departments, and in particular big city police departments. ${ }^{30}$ By 1997, local crime prevention took a bigger slice of the Justice Department's budget than the FBI, DEA, or INS. In fact, among all Justice components, only the Bureau of Prisons got more than the units that funneled money to state and local enforcers. ${ }^{31}$

How dependent did state and local governments become on this federal assistance? The answer eludes easy quantification. ${ }^{32}$ Yet in California, where the annual expenditures on law enforcement agencies ranged between $\$ 7$ and 8.7 billion in 1995$98,{ }^{33}$ the Legislative Analysis Office could report that the agencies had received "almost \$343 million through the COPS program” between 1995 and 1997, "almost \$72 million in block grants" in 1997 alone, and could expect “almost \$50 million” in Byrne grants for 1998. ${ }^{34}$ And it advised that, given this influx of federal funds to state police agencies, the Legislature need to determine "whether state funds for law enforcement [could] be reduced or redirected to other parts of the criminal justice system that have not received new federal monies." 35

This is not the place to debate whether these federal grant programs achieved or even furthered their stated goal of crime reduction. I don't even want to venture into the controversy of how many more cops ended up patrolling the streets. ${ }^{36}$ From the

\footnotetext{
${ }^{28}$ Pub. L. 103-322; also see JoAnne O’Bryant, Crime Control: The Federal Response, CRS (updated Mar. 5 , 2003) (order code 1B10095).

${ }^{29}$ Jeffrey Roth, et al., National Evaluation of the COPS Program - Title I of the 1994 Crime Act, at 41 (National Institute of Justice) (NCJ 183643, Aug. 2000).

${ }^{30}$ Id. at 10 (of all agencies awarded grants under the COPS program by end of 1997 "only $4 \%$ served core city jurisdictions. But they received $40 \%$ of COPS dollar awards for all programs combined and $62 \%$ of all COPS MORE [“Making Officer Redeployment Effective"] funds (which went to technology, civilians, and overtime"); see also id. at 65 ("On both the per capita and per crime bases, mean awards to core cities were highest in the Middle Atlantic region and lowest in the West South Central region.”).

${ }^{31}$ Lawrence W. Sherman, et al., Preventing Crime: What Works, What Doesn't, What's Promising, A Report to the U.S. Congress, prepared for NIJ, at 1-11 (Feb. 1997), available at http://www.ncjrs.org/works/index.htm

${ }^{32}$ See Richard P. Nathan, State and Local Governments under Federal Grants: Toward a Predictive Theory, 98 Pol. Sci. Q. 47 (1983).

${ }^{33}$ Calif. Dep’t of Justice, Criminal Justice Fiscal Expenditures, available at http://justice.hdcdojnet.state.ca.us/cjsc_stats/prof01/00/10.htm.

${ }^{34}$ State of California, Legislative Analyst’s Office, Analysis of the 1998-99 Budget Bill Criminal Justice Cross-Cutting Issues, at 19-20, available at http://www.lao.ca.gov/analysis_1998/crim_justice_crosscutting_anl98.html

${ }^{35}$ Id. at 24.

${ }^{36}$ Compare Office of the Inspector General, Management and Administration of the Community Oriented Policing Services Grant Program, July 1999 (exec. summary) (audit finding inadequacies in program), available at www.usdoj.gov/oig/au9921/9921toc.htm, with Roth, supra note _, at 56 (discussing audit),
} 
intergovernmental perspective, the only important point is that the latter part of the 1990s marked the high-water mark of a federal-state-local relationship, based on violent crime enforcement, that (surprise, surprise) nicely served the interests of all most of the governmental actors involved. Presidential administrations of both parties got to tout their commitment to the Fight against Crime and the War on Drugs. Legislators, who readily appropriated large sums of money for these endeavors, could tout their commitment as well, but there was more to it than that. For the essence of the violent crime targeted by the enforcement and funding programs discussed here was local. While there was much talk, and perhaps some reality, of coordination, innovation, and "best practices," the thrust of these programs was to deploy federal dollars and manpower against local problems. And with each conspicuous deployment, be it funding grant or enforcement program, a legislator's press release could take some credit. Congressional representatives could also take credit for relieving local enforcers of burdensome grant compliance. $^{37}$ The interests of Federal enforcement agencies were also well served by the new violent crime priorities. The general public was happy to see the "feds" deployed against local bad guys - street gangs, armed robbers, and murderers. And the championship of these cases by local legislative delegations could only redound to the benefit of agencies at funding time, and to field offices in their relations with headquarters. The timing for the FBI was particularly propitious, as the end of the Cold War allowed the redeployment of agents from counterintelligence to anti-violence assignments. $^{38}$ Even better, was the extent of federal enforcement discretion in this area. There may have been political pressure to do violent crime cases. But there was little pressure to any particular case. Violent crime was still, after all, primarily a local responsibility. Federal agencies thus could be quite strategic in their case selection decisions.

Local enforcers welcomed the federal enforcement and funding assistance. The Supreme Court might bemoan federal intrusion into a traditionally local domain. ${ }^{39}$ But local enforcers had less interest in airy notions of dignity and accountability, and more in direct grants, overtime pay, and the aid-in-kind that federal enforcement activity - and

with See David B. Muhlhausen, Why the Bush Administration Is Right on COPS, Heritage Foundation Backgrounder \#1647 (Apr. 23, 2003) (scathing attack on COPS program), available at http://www.heritage.org/Research/Crime/bg1647.cfm; see also Office of the Comptroller, City of New York, The State of the City's Economy and Finances, 16 (Dec. 26, 2003) (noting that New York City used COPS money to hire about 3500 police officers between 1997 and 2000), available at http://www.comptroller.nyc.gov/bureaus/bud/reports/stateofthecity2002.pdf.

${ }^{37}$ See John E. Chubb, The Political Economy of Federalism, 79 Am. Pol. Sci. Rev. 994, 1005 (1985) ("Congressional pressures [] can cut a bureaucracy in two ways: with general signals for stronger or weaker enforcement [of spending regulations], and with selective constituency-specific signals to ensure compliance or provide regulatory relief.”).

${ }^{38}$ See David Johnston, FBI to Shift from Cold War to Crime War, N. Y. Times, Jan 9, 1992, at _. Note that given what we know about counterintelligence weaknesses during this period, see Mark Reibling, Wedge: From Pearl Harbor to 9/11, How the Secret War Between the FBI and CIA Has Endangered National Security, the Bureau's confidence may have been misplaced. See also Office of the Inspector General, Dep't of Justice, A Review of the FBI's Performance in Deterring, Detecting, and Investigating the Espionage Activities of Robert Philip Hanssen (Aug. 2003) (unclassified executive summary), available at http://www.usdoj.gov/oig/special/03-08/final.pdf.

39 See United States v. Lopez, 514 U.S. 549 (1995). 
the significant procedural and sentencing advantages flowing therefrom -- really amounted to. ${ }^{40}$ After all, despite the occasional turf-battle, the fact is that federal agencies can rarely do violent crime cases without the help of the local police, who alone control "the informational networks on which federal law enforcement agencies must rely when pursuing episodic criminal activity." 41 So although judges decried the flood of "state" cases into federal court, ${ }^{42}$ and defendants who expected to be prosecuted in state court, complained when they were somewhat arbitrarily selected out for harsher federal sentences, ${ }^{43}$ state and law enforcers could and did look on this federal "intrusion" with equanimity, and sometimes even glee.

This decade of direct grants, block grants, and enforcement assistance from the federal government to state and local authorities did not come to an end with the election of George W. Bush. With great fanfare, the new President announced an "Initiative to Reduce Gun Violence,” and, as he had in his campaign, embraced a program of maximal federal involvement in gun violence prosecutions. ${ }^{44}$ And in a May 2001 memo to department heads, Attorney General Ashcroft included, as two of his seven goals, "reducing drug violence and drug trafficking," and "helping states with anti-crime programs." He did not even mention terrorism. ${ }^{45}$ To be sure, the new Administration announced plans to phase out the COPS program ${ }^{46}$ - not that surprising, given that Republicans had long questioned of the efficacy of this Clinton program that tended to funnel most of its money to big city Democratic strongholds. ${ }^{47}$ But the plan envisioned a reconfiguring of federal aid in the violent crime area, not a transfer away from it. ${ }^{48}$

\footnotetext{
${ }^{40}$ See Gerald R. Murphy \& Martha R. Plotkin, Protecting Your Community from Terrorism: The Strategies for Local Law Enforcement Series, Vol. I: Improving Local-Federal Partnerships, Mar. 2003, at 50 (Police Executive Research Forum \& Community Oriented Policing Services, Dept of Justice) (police chief notes that many chiefs like FBI to do drug, bank robbery \& violent crime cases. "We want it both ways."); see also Daniel Richman, Boundaries, supra note _ , at 95.

${ }^{41}$ Daniel C. Richman, Federal Criminal Law, Congressional Delegation, and Enforcement Discretion, 46 UCLA L. Rev. 757, 785 (1999).

${ }^{42}$ See Daniel Richman, Prosecutors and Their Agents, Agents and Their Prosecutors, 103 Colum. L. Rev. 749, 795 (2003) (collecting cites).

${ }^{43}$ See Steven D. Clymer, Unequal Justice, The Federalization of Criminal Law, 70 S. Cal. L. Rev. 643 (1997).

${ }^{44}$ See Remarks by President George W. Bush and U.S. Attorney General John Ashcroft, Initiative to Reduce Gun Violence, May 14, 2001 (Federal News Service). See also Project Safe Neighborhoods website, http://www.psn.gov/

${ }^{45}$ Adam Clymer, How Sept. 11 Changed Goals of Justice Dept., N.Y. Times, Feb. 28, 2002, at _ . Ashcroft did mention terrorism when testifying before the Senate Appropriations Committee in April 2001, but his focus there too was on violent crime. See Jerry Seper, Justice Budget Targets Drug Use, Gun Crimes, Attacks on Women, Wash. Times, Apr. 27, 2001, at A5; see also Joint Intelligence Committee Report, _ _ ("An FBI budget official told the Joint Inquiry that counterterrorism was not a priority for Attorney General (John) Ashcroft before Sept. 11, and the FBI faced pressure to make cuts in counterterrorism to satisfy his other priorities.”).

${ }^{46}$ See Jim Oliphant, DOJ Trims State Funds, Legal Times, Apr. 16, 2001, at 18.

${ }^{47}$ As far back as 1995, one part of the Republican Contract with America, proposed in H.R. 3, $104^{\text {th }}$ Cong., $1^{\text {st }}$ sess. (1995), would have eliminated the COPS program in favor of a block-grant program See Philip B. Heymann \& Mark H. Moore, The Federal Role in Dealing with Violent Street Crime: Principles, Questions, and Cautions, 543 Annals of Amer. Acad. Pol. \& Soc. Sci. 103, ${ }^{48}$ Oliphant, supra note (1996).
} 
Then came the attacks on September 11, 2001.

\section{The Post-9/11 Dynamic}

We are often told that September 11 "changed everything." Perhaps this is an overstatement in some contexts. But I believe the assessment dead on when applied to the federal, state and local law enforcement dynamic.

The shock to the federal enforcement bureaucracy was extraordinary. Before this, there were a few specialized "beats” that the feds had to patrol. ${ }^{49}$ But the system's defining luxury was the absence of any responsibility to pursue any particular case in most of the areas in which it had jurisdiction. Now, all of a sudden, it was saddled with a politically unavoidable, ${ }^{50}$ and all-but-impossible responsibility: preventing another such attack.

To their credit, federal enforcement officials made a concerted effort to reach out to state and local agencies for intelligence-gathering assistance, and diplomatically sought to address long-standing local complaints about the feds' reluctance to share information. FBI Director Mueller made conciliatory speeches, ${ }^{51}$ and created a new Office of Law Enforcement Coordination, headed by a former police chief, within the FBI. $^{52}$ Attorney General Ashcroft announced the creation of Anti-Terrorism Task Forces within each district, and set up mechanisms for these units to coordinate with state and local authorities. ${ }^{53}$ (These "task forces," with their outreach function, are not to be

${ }^{49}$ See Richman, Federal Criminal Law, supra note _ , at 766.

${ }^{50}$ See Edward J. Tully (retired FBI agent - 31 yrs service) \& E.L. (Bud) Willoughby (retired chief, Salt Lake City police), Terrorism: The Role of Local and State Police Agencies, website: National Executive Institute Association, Major Cities Chiefs Assn \& Major County Sheriff's [sic] Association, at 7 (May 2002) (-If you are mayor or chief of police in a major city, "Your unquestioned legal responsibility is to provide safety and security to your citizens. In reality, however, you have sub-contracted this protection to the federal government and its various agencies."), available at http://www.neiaassociates.org/state-local.htm (accessed June 2, 2003); see also Gov't Accounting Office. Homeland Security: Efforts to Improve Information Sharing Need to be Strengthened, GAO-03-760, at 7 (Aug. 2003) ("Preventing the United States from terrorism has traditionally been a responsibility of the federal government and, typically, the views of states and cities in formulating national policy have not been considered").

${ }^{51}$ Remarks by Robert S. Mueller III, Director, FBI, at the Mayors Emergency, Safety, and Security Summit United States Conference of Mayors,October 24, 2001, available at

http://www.fbi.gov/pressrel/speeches/mayors.htm; Remarks Prepared for Delivery by Robert S. Mueller III, Director, FBI, at the Annual Meeting of the Police Executive Research Forum, May 9, 2002, available at http://www.fbi.gov/pressrel/speeches/speech050902.htm

${ }^{52}$ FBI, Press Release, Apr. 11, 2002, available at http://www.fbi.gov/pressrel/pressrel02/mueller041102.htm

${ }^{53}$ Dept. of Justice. Fact Sheet: Overview of Information Sharing Initiatives in the War on Terrorism, available at http://www.cdt.org/security/usapatriot/020923overview.pdf;

Memorandum of Atty. Gen. John Ashcroft to All U.S. Attorneys, Cooperation with State and Local Officials in the Fight Against Terrorism, Nov. 13, 2001, available at http://www.fas.org/irp/agency/doj/agdirective5.pdf; see also Century Foundation: Steven D. Stehr, Homeland Security in the State of Washington: A Baseline Report on the Activities of State and Local 
confused with the Joint Terrorism Task Forces, which have more of an operational role.) ${ }^{54}$ The Office of Homeland Security and, after the up-grade, the Department of Homeland Security also sought to facilitate intergovernmental cooperation. ${ }^{55}$

These moves all testified to the new intergovernment intelligence dynamic. Given the nature of the perceived terrorist threat - the sleeper cells waiting to strike again $^{56}$---- federal agencies now relied on the intelligence capabilities of local police forces in a way they never did when the primary area of interaction was violent crime. Back then, the feds needed help from the locals, but since they could walk away from any case and had could offer many benefits, they had considerable leverage. Now, the rush was on to create the semblance of a national intelligence network providing what Philip Heymann has called "untargeted prevention." 57 And, in this, the participation of local cops was absolutely essential.

What state and local enforcers bring to the counterterrorism intelligence-gathering process is not simply a function of their numbers - 638,066 state and local police officers compared to 88,496 federal law enforcement officers (more than a quarter of whom were in the Federal Bureau of Prisons) in $1999-2000^{58}$ - nor even of the many things they learn

Govts at 24 (2003) (purpose of the Anti-Terrorism Task Force "is to centralize the process by which information relevant to the investigation and prosecution of terrorists can be shared with state and local officials.”).

${ }^{54}$ See Richard B. Schmitt \& Greg Krikorian, Foot Soldiers on the Homeland Security Front; The FBI is Relying on Task Forces of Federal, State and Local Law Enforcement Officials, L.A. Times, Apr. 21, 2003, at 18. The likelihood of confusion between the two different "task forces," may explain why the Justice Department recently changed the name of the "Anti-Terrorism Task Forces," to "Anti-Terrorism Advisory Councils.” See Press Release, Dep’t of Justice, “Attorney General John Ashcroft Announces Changes to Anti-Terrorism Task Forces, Sept. 25, 2003. available at http://www.usdoj.gov/opa/pr/2003/September/03_ag_528.htm.

${ }^{55}$ See Daniel Richman, Prosecutors and Their Agents, Agents and Their Prosecutors, 103 Colum. L. Rev. 749, 769 n. 83 (2003).

${ }^{56}$ See Karen DeYoung, "Sleeper Cells” Of Al Qaeda Are Next Target; U.S. to Focus on Terror Threat As Afghan Effort Winds Down, Wash. Post, Dec. 3, 2001, at A1.

57 See Philip B. Heymann, Terrorism and America: A Commonsense Strategy for a Democratic Society 80-82 (MIT Press 1998) (comparing "targeted prevention" - where subjects \& plans are known -- with "untargeted prevention" - whose "purpose is to make it more risky and difficult to carry out a bombing or other terrorist act and thereby to reduce that level of terrorist events by, at a minimum, increasing the time, expense, and effort for each, and perhaps also reducing what may be a very limited total pool of participants by discouraging beginner, increasing defections, and incapacitating the firmly committed."); see also National Strategy for Homeland Security (July 2002) (stating goal of "build[ing] a national environment that enables the sharing of essential homeland security information horizontally across each agency of the federal government and vertically among federal, state, and local governments, private industry, and citizens”).

${ }^{58}$ See Sourcebook of Criminal Justice Statistics 2001, at 33, tbl. 1.22; Brian A. Reeves \& Timothy C. Hart, Bureau of Justice Statistics, Federal Law Enforcement Officers, 2000, at 8 (July 2001). The years given are the last for which state and local data are available. The number of federal officers climbed to 93,446 by June 2002. Brian A. Reeves \& Lynn M. Bauer, Federal Law Enforcement Officers, 2002, at 8 (Aug. 2003). 
while on street patrol. It also stems from their involvement in bringing the bulk of serious criminal charges in the United States, ${ }^{59}$ because the threat of prosecution (even prosecutions having nothing to do with terrorism) is one of best tools around for prying loose closely held information. Their order maintenance and public safety duties also give local police a more balanced "portfolio" in dealing with community leaders. The police officer who seeks information from a local Arab-American community leader has probably met, and assisted that leader before. ${ }^{60}$

The Justice Department quickly went beyond vague talk of "information sharing” and asked for local assistance in a large-scale program to interview thousands of people (mostly young Middle Eastern males) in the country on non-immigrant visas. ${ }^{61}$ In the Spring of 2002, the Department went further and announced its plan to place of names of certain aliens who had violated their visa requirements into the national database of wanted suspects. It asked state and local police to arrest these "absconders," and noted that, as a legal matter, such assistance was "within the inherent authority of the states."62

\footnotetext{
${ }^{59}$ In 2001, there were an estimated 13,699,254 arrests in the U.S., , including 2,245,597 for index crimes. See Sourcebook of Criminal Justice Statistics Online, tbl. 4.1 ("Estimated number of arrests"). Between Oct. 1, 2000, and Sept. 30, 2001, 118,896 suspects were arrested on federal charges and processed by federal marshals. Bureau of Justice Statistics, Federal Criminal Case Processing, 2001, tbl. 1, available at http://www.ojp.usdoj.gov/bjs/pub/pdf/fccp01.pdf.

${ }^{60}$ See Murphy \& Plotkin, supra note _ , at 43 "Local law enforcement can facilitate information gathering among community groups with whom they have good relationships. Community advisory boards that include Arab and Muslim members, for example, can be brought together for meetings with the FBI to provide information.”); Siobhan Gorman, National Journal, Mar. 29, 2003 (Director of Detroit American Arab Chamber of Commerce notes "that while the local Police Department has worked to win the Arab community's trust and has Arab-Americans within its ranks, the FBI and other federal law enforcement agencies haven't done enough to establish trust. Last week, after the war broke out, the Wayne County sheriff dispatched his forces to guard mosques here. 'There weren't any incidents or any problems in the area,' said Mohammad Ali Elahi, the imam at the Islamic House of Wisdom here. 'The interaction between authorities and community has been very fruitful.'”); Maryanne George, Criticism After Sept. 11: Words from Police Chief in Spotlight, Detroit Free Press, Dec. 4, 2001, at _ (chief of Ann Arbor, Mich., police notes that leaders of local Arab-American community had asked that officer from his force be present during post 9/11 FBI interviews of Arab-Americans).
}

${ }^{61}$ See Allan Lengel, Arab Men in Detroit to be Asked to See U.S. Attorney, Wash. Post, Nov. 27, 2001, at A5; Samuel R. Gross \& Debra Livingston, Racial Profiling Under Attack, 102 Colum. L. Rev. 1413, 141718 (2002; Memorandum from the Attorney General to All U.S. Attorneys; All Members of the AntiTerrorism Task Forces, Interviews Regarding International Terrorism, Nov. 9, 2001, available at http://www.usdoj.gov/ag/readingroom/terrorism1.htm; Memorandum from the Deputy Attorney General to All U.S. Attorneys; All Members of the Anti-Terrorism Task Forces, Guidelines for the Interviews Regarding International Terrorism, Nov. 9, 2001, available at http://www.usdoj.gov/04foia/readingrooms/terrorism2.htm.

${ }^{62}$ As Attorney General Ashcroft explained when announcing the "National Security Entry-Exit Registration System,” June 6, 2002, http://www.immigration.gov/graphics/preparedremarks.htm: "When federal, state and local law enforcement officers encounter an alien of national security concern who has been listed on the NCIC for violating immigration law, federal law permits them to arrest that individual and transfer him to the custody of the INS. "The Justice Department"s Office of Legal Counsel has concluded that this narrow, limited mission that we are asking state and local police to undertake voluntarily -- arresting aliens who have violated criminal provisions of Immigration and Nationality Act or civil provisions that render an alien deportable, and who are listed on the NCIC — is within the inherent authority of the states. The Department of Justice has no plans to seek additional support from state and 
Before focusing on the local response to these particular federal initiatives, one should note that the predominant response of local police forces to the federal calls for assistance in the War on Terror was to line up at the recruiting station and complain about delays. Big city police forces moved to relax the intelligence gathering restrictions that had been imposed in the wake of abuses in the 1960s and 1970s. ${ }^{63}$ And the constant drumbeat from police departments during 2002 and into 2003 was that the feds weren't sharing information with the locals, weren't putting them "'in the game.,"64

Some police officials strategically pivoted off calls for counterterrorism intelligence gathering and called for the creation of a more general criminal intelligencesharing plan, to be superintended by the locals. A 2002 intelligence summit of the International Association of Chiefs of Police produced a "vision" "in which state and local agencies are not merely adjuncts to a national strategy for improving intelligence communication, but founding partners of and driving participants in any organization that helps coordinate the collection, analysis, dissemination and use of criminal intelligence data in the U.S."65

That said, conditions were not altogether propitious for police cooperation. In a number of cities and states (by July 2003, 3 states and 165 local governments), officials

local law enforcement in enforcing our nation's immigration laws, beyond our narrow anti-terrorism mission.”); see also Cheryl W. Thompson, INS Role for Police Considered; U.S. Eyes State, Local Help in Enforcing Immigration Laws, Wash. Post, Apr. 4, 2002, at A15.

63 See Handschu v. Special Services Division, 2003 U.S. Dist. Lexis 2134 (S.D.N.Y. 2003) (ruling on efforts of N.Y. Police Department to relax guidelines governing investigation of political activity; Michael Powell, Domestic Spying Pressed; Big-City Police Seek to Ease Limits Imposed After Abuses Decades Ago, Wash. Post, Nov. 29, 2002, A1 ("In Chicago, officials have already weakened a court decree limiting police spying. In San Francisco, officials have reversed their own 1997 decision and have now joined an FBI terrorism task force, even though FBI surveillance of mosques and peaceful protests could violate the California constitution.”).

${ }^{64}$ Murphy \& Plotkin, supra note _, 9 (complaints by local officials that, for FBI, information sharing is only one-way); id. at 29 (more than year after attacks, local law enforcement executives "do not feel like they are in the game.” (commentary by Edward A. Flynn, Sec. of Public Safety for Massachusetts, former Chief of Arlington Co. (Va) Police Department); id. at 33 (complaints by local officials that FBI does not take them up on offers of resources); Tully \& Willoughby, supra note _, at 7 ("state and local officials should demand respect and equality when dealing with federal agencies. Withholding information, making unilateral decisions, or ignoring the legitimate concerns of local officials by federal officials should be deemed unacceptable. When state and local officers participate in joint task forces they should do so only on the condition that they are treated as equals and that their superiors are fully information about matters of critical importance.”). See also Gov't Accounting Office. Homeland Security: Efforts to Improve Information Sharing Need to be Strengthened, GAO-03-760, at 18 (Aug. 2003) (noting state and local complaints in 2002 about insufficient federal information sharing, and finding "little change" a year later).

${ }^{65}$ Criminal Intelligence Sharing: A National Plan for Intelligence-Led Policing at the Local, State and Federal Levels: Recommendations from the IACP Intelligence Summit, at 2 (Aug. 2002): available at http://www.theiacp.org/documents/pdfs/Publications/intelsharingreport.pdf. 
took stands (pretty symbolic, to be sure ${ }^{66}$ ) against the Administration's counter-terrorism efforts. The town of Arcata (population 16,000) barred its officials from assisting in investigations carried out under the USA Patriot Act; officials who don't tell the city manager when contacted by federal authorities pursuing investigations under the Act are to be fined $\$ 57 .{ }^{67}$ The Seattle city council reaffirmed its support for an ordinance limiting the ability of local police to gather or share information on religious or political groups.”" ${ }^{68}$ Some stands were more than symbolic. In December 2001, notwithstanding opinions to contrary by the Oregon attorney general and local district attorney, the Portland City Attorney announced that state law - barring police police from "detecting or apprehending” people who have violated only fed immigration law, and from collecting info on political, social or religious beliefs unless it pertains to a criminal investigation - prohibited Portland police from asking some of the 33 questions that the Justice Department wanted posed to 23 foreigners in area. ${ }^{69}$

Some of this scattered resistance may have arisen from partisan politics or liberal reflexes. But there was a historical basis as well, for the federal efforts to recruit local police into a national intelligence network brought back memories of 1968, when the feds had urged the locals to create "'intelligence units" to gather and disseminate information on "potential" civil disorders.",70 The Church Committee later recounted the result of these efforts: "Local police intelligence provided a convenient manner for the FBI to acquire information it wanted while avoiding criticism for using covert techniques such as developing campus informants. For example, in 1969, Director Hoover decided "that additional student informants cannot be developed" by the Bureau. Field offices were instructed, however, that one way to continue obtaining intelligence on "situations having a potential for violence" was to develop "in-depth liaison with local law enforcement agencies. " Instead of recruiting student informants itself, the FBI would rely on local police to do so." "These Federal policies contributed to the proliferation of local police

\footnotetext{
${ }^{66}$ See Michael Riley, Denver Post, Limits on Terror Fight Eyed, Mar. 15, 2002, at A1 (reporting police as saying that "most rank and file police work is unlikely to be affected by the resolution." "'The FBI rarely asks us for help. They don't need to,' said David Nell, president of the Denver police union. 'This is about as relevant as the nuclear-free zone in Boulder.'”).

${ }^{67}$ Guy Taylor, Communities Shun Patriot Act, Wash. Times, July 21, 2003, at _; Richard Lacayo, The War Comes Back Home; Can Attorney General John Ashcroft Fight Terrorism on Our Shores Without Injuring Our Freedoms?, Time Magazine, May 12, 2003 ("Nearly 100 towns and counties, plus the state of Hawaii, have passed resolutions condemning the USA Patriot Act....”).; see also Scott Martelle, New Breed of Patriots Speaking Up; Grass-roots Efforts to Rein In the Anti-Terrorist USA Patriot Act Gain Support, LA Times, Dec. 8, 2002, at 24: Michael Janofsky, Cities Urge Restraint in Fight Against Terror, NY Times, Dec. 23, 2002. For a list of cities, see http://www.bordc.org/Chronology.pdf

${ }^{68}$ See Jim Brunner, Seattle Council Takes Aim at USA Patriot Act, Seattle Times, Feb. 19, 2003, at B3 (noting the passage of similar resolutions in Oakland, San Francisco, Detroit, Denver, and Cambridge, Mass.).

${ }^{69}$ See AP, Portland Chief Denies City Not Cooperating, Seattle Times, Dec. 3, 2001, at _.

${ }^{70}$ Church Committee Report: Intelligence Activities and Rights of Americans, Bk. II, Final Report of the Senate Select Committee to Study Governmental Operations With Respect to Intelligence Activities, at 332-33 (Apr. 26, 1976), available at http://www.icdc.com/ paulwolf/cointelpro/churchfinalreportIIb.htm
} 
intelligence activities, often without adequate controls. One result was that still more persons were subjected to investigation who neither engaged in unlawful activity, nor belonged to groups which might be violent." ${ }^{\text {,1 }}$ All this was not ancient history to local authorities in places like Denver, which in 2002 was still negotiating a settlement with the ACLU relating to abuses by the police intelligence bureau, and New York City, where a consent degree arising out of similar abuses is still in place. ${ }^{72}$

Local concerns were not merely partisan, philosophical or historical. They also grew out of local politics. When the federal-local interaction was centered on violent crime, federal initiatives brought significant positive externalities - credit for local leaders and maybe even improved local safety. The counterterrorism dynamic has been precisely the reverse (with some important exceptions, e.g. NYC). There is no reason to expect that terrorists pose a particular threat to the many of the places where they or information about them will be found. (Detroit is a great example.) In those areas, the gains from domestic intelligence gathering thus are felt primarily, even exclusively at the national level. But the costs of gathering fall on the localities. And I am not even talking about the fiscal cost right now, but rather to the significant negative externalities that attend any large-scale investigations of immigrant activities in communities that have large numbers of immigrants.

Police department, of course, don't always share the concerns of their political masters. But police officials have had their own pragmatic concerns about federal counterterrorism initiatives, particularly those involving the use of federal immigration statutes. As the "chief counsel's column" on the website of the International Association of Chiefs of Police explained in the Fall of 2002:

[E]nforcement of civil immigration laws by local law enforcement would have a chilling effect on both legal and illegal aliens reporting criminal activity or assisting police in criminal investigations. Local police want illegal aliens to come forward when they have been the victims of, or witnesses to, crimes. Police depend on the cooperation of immigrant communities to help them solve all sorts of crimes and to maintain public order. Without the assurances that they will not be deported, many illegal immigrants with critical information would not come forward.",73

\footnotetext{
${ }^{71}$ Id. at 332-35 (??).

72 See Handshu v. Special Services Div., supra note __; Ford Fessenden \& Michael Moss, Going Electronic, Denver Reveals Long-Term Surveillance, N.Y. Times, Dec. 21, 2002, at A12; Mike McPhee, "Spy files” Shared with FBI, Others; Feds Say Information From Denver Deleted, May 16, 2003, at A27; Kevin Vaughan, Police Will Still Gather Intelligence; But "Spy Files” Settlement Places Restrictions on How It Can Be Done, Rocky Mountain News, Apr. 18, 2003, at A12; Michael Riley, Denver Post, Limits on Terror Fight Eyed, Mar. 15, 2002, at A1.

${ }^{73}$ Craig E. Ferrell Jr. (“Deputy Director, Administrative General Counsel, Chief's Command Legal Services, Houston, Texas, Police Department”) The War on Terror's “Absconder Initiative,” (“Chief Counsel’s Column,” website of The International Association of Chiefs of Police), dated 10/1/02; SEN JUD COMM HEARINGS FOR 9/03 CANCELLED. ADD CITES IF/WHEN HEARINGS HELD.
} 
A Georgia police chief recalled that, after police had taken part in several INS raids to round up illegal immigrants in the early 1990s, "[v]ery quickly, people in the community associated us with the INS. That's exactly what you don't want.” He called the Justice Department's proposal "a horrible idea.,74 Other police chiefs expressed similar sentiments. ${ }^{75}$ One congressional representative recently reported on her conversations with police officials in California "that most police chiefs and most local law enforcement agencies oppose the idea of having to enforce immigration laws. Some of them oppose it because it adds an additional burden on them in trying to carry out their local law enforcement duties. And others oppose it because they fear that that would create a risk with the very immigrant communities that they seek assistance from or information from in helping enforce local laws ....”76

Few non-federal enforcement officials seemed disposed to assist the feds in using the immigration laws as a law enforcement tool, even though, as one federal official noted, "the only barriers to executing such arrests are statutes or policies that states or municipalities have imposed upon themselves."77 Indeed, it's interesting to note that perhaps the biggest local initiative in the immigration area during this period was the readiness to allow illegal Mexican immigrants to use identification cards issued by the Mexican government, ${ }^{78}$ a practice that an FBI official says "poses a criminal and terrorist

\footnotetext{
${ }^{74}$ Rick Badie, Police Uneasy About Helping Arrest Illegals; Ashcroft Favors Local Assistance, Atlanta Journal-Constitution, Apr. 10, 2002., at 1JJ (quoting police chief of Chamblee, Ga.).
}

\footnotetext{
${ }^{75}$ See Cheryl W. Thompson, INS Role for Police Considered; U.S. Eyes State, Local Help in Enforcing Immigration Laws, Wash. Post, Apr. 4, 2002, at A15: (Chicago police official notes: "“We have an executive order from the mayor's office where we don't do anything with immigration;”’ D.C. Police Chief Charles H. Ramsey expresses "concern that using local police to enforce immigration laws would thwart efforts to build relationships with immigrant communities.”);;Diana Marrer, Experts: Do Not Mix INS, Police; S. Floridians Criticize Plan By Ashcroft, Sun-Sentinel (Ft. Lauderdale, Fla), Apr. 25, 2002, 1B (Miami PD spokesman says "'We will not function in an INS capacity.... It's not our job. Our job is to solve crimes.”' Hollywood (Fla.) detective says “'police need to have the confidence of their communities.””); Hearing, Immigration Enforcement Since Sept. 11, 2001, Border Security \& Claims Subcomm., House Jud. Comm., FDCH Pol. Trans., May 8, 2003 (ACLU witness quotes Montgomery Cty police chief Charles Moose: “'Now this movement by the federal government to say that they want local police officer to become INS agents is against the core values of community policing, partnerships, assisting people and being there to solve problems.””). For more quotes from local law enforcement officials and others against local enforcement of immigration laws, see http://www.immigrationforum.org/currentissues/articles/100102_quotes.htm.

${ }^{76}$ Hearing, Immigration Enforcement Since Sept. 11, 2001, Border Security \& Claims Subcomm., House Jud. Comm., FDCH Pol. Trans., May 8, 2003, at 21 (comments of Rep. Linda Sanchez (D-Ca.)).
}

77 Letter \& Report of Jamie E. Brown, AAG Leg Affairs, to Hon. F. James Sensenbrenner, Jr., Chrm., House Jud. Comm., May 13, 2003, at 60 (responding to Committee inquiries concerning USA Patriot Act implementation and related matter), available at http://www.house.gov/judiciary/patriotlet051303.pdf.

${ }^{78}$ See Audrey Hudson, Mexico’s ID Card Gain More Acceptance in States, Cities, Wash. Times, June 14, 2003, at A1 ("The Mexican government is convincing hundreds of local government and police departments across the United States to accept its identification cards used by legal and illegal aliens, which 
threat." ${ }^{\text {,79 }}$ The non-federal officials most disposed to assist in enforcing the immigration laws seem to come from the state level, not the local. The New York story is revealing. In early 2002 (if not before), James Kallstrom, the State’s “counterterrorism czar,” was said by State Police Superintendent James McMahon, to have asked DOJ to "crosslicense local police," to allow them to arrest undocumented immigrants. "'Everything we're trying to do here in this effort to prevent (terrorism) is to utilize the full resources of 70,000 state and local cops in New York state ....”, ${ }^{\prime 80}$ Thereafter, Governor Pataki put the plan on hold, reportedly "because of mounting opposition from civil libertarians and immigrant groups who fear police would engage in racial profiling and harass otherwise law-abiding people who are in the country illegally." ${ }^{\text {"11 }}$ Perhaps even more revealing is the dynamic in Maryland. There, "[m]any local police departments [], including those in Baltimore and in Anne Arundel and Baltimore counties, generally will not report illegal immigrants unless they have committed crimes." ${ }^{82}$ However, "state police policy is to information federal authorities about any suspected of being in the country illegally.",83 As of the summer of 2003, only Florida and Alabama had formally signed on to the federal initiative, and in Alabama it appears that only state troopers are involved. ${ }^{84}$ A bill has been introduced in the House - the "Clear Law Enforcement for Criminal Alien Removal Act of 2003"85 - that would require state and local authorities to enforce federal immigration laws, on pain of losing federal funds. At an October 2003 hearing, the

critics say amounts to a backdoor amnesty for illegal aliens."); see also Matthew Mosk, Montgomery to Allow Consular ID Cards, Wash. Post, May 29, 2003, at A10. A bill to limit the use of these cards was passed by the House on July 16, 2003, as part of the Foreign Operations authorization bill. See Stephen Dinan, House Bill Restricts Consular I.D. Card, Wash. Times, July 17, 2003, at _.

\footnotetext{
${ }^{79}$ Stephen Dinan, Mexican ID Not Valid, a “Threat,” FBI Says, Wash. Times, June 27, 2003.

${ }^{80}$ Brendan Lyons, Local Police, Federal Powers; Feds Are Asked to Grant New York State’s Officers Authority to Make Immigration Arrests, Times Union (Albany, NY), Mar. 22, 2002, at A1.

${ }^{81}$ Brendon Lyons, Pataki Waits on Cop Plan; Concerns Delay Proposal to Give Police Power to Act as INS Agents, Times Union (Albany, NY), Apr. 11, 2002, at A1; see also Susan Sachs, Mayor's New Immigrant Policy, Intended to Help, Raises Fears, N.Y.Times, July 23, 2003, at A1 (discussing City policies regarding reporting of resident's immigration status to federal authorities).
}

${ }^{82}$ Jason Song, Local Police May Get Role in Immigrant Law; Federal Bill to Address Disparities Among Agencies, Baltimore Sun, July 9, 2003, at 1B.

${ }^{83}$ Id.

${ }^{84}$ Hearing, Immigration Enforcement Since Sept. 11, 2001, Border Security \& Claims Subcomm., House Jud. Comm., FDCH Pol. Trans., May 8, 2003 (testimony of Michael Dougherty, Staff Dir of Operations, Bureau of Immigration \& Customs Enforcement) )( reporting "a limited program in Florida and, perhaps, a beginnings of a program in another one of the southern states .... The delegation of authority under Section 287(g) in the [Immigration \& Nationality] act really is currently only provided in the state of Florida.");

Rachel L. Swarns, Immigrants Feel the Pinch of Post-9/11 Laws, NY Times, June 25, 2003, at A14: "Last month, [] about 600 Alabama state police officers sat down for their first classes in civil immigration law. By the end of the year, officials say, a small team of local police officers there will have the power to arrest illegal immigrants for the first time in recent memory.”); Ginny MacDonald, Trooper Authority on Immigration Opposed Hispanic Leaders Say New Powers Could Violate Rights, Birmingham (Ala.) News, Mar. 6, 2003.

${ }^{85}$ H.R. 2671. 
National League of Cities expressed its opposition for what it characterized as an "unfunded mandate," 86 and the legislation's future remains unclear.

Why the difference between the attitudes of local police departments and their statewide counterparts? Straightforward political differences may play a part here Republican governors versus more liberal urban local officials. But institutional obligations (or the lack thereof) likely play a role as well. For it is at the local level and particularly in big cities, that the costs imposed by the federal enforcement initiative on relationships with immigrant communities would hit hardest.

Even had nothing else changed in the relationship between federal and local enforcers, the new federal counterterrorism initiatives would have imposed new intelligence gathering responsibilities on the police and arguably have made it harder to maintain order in areas with significant immigrant populations, including most big cities. But the costs effectively imposed on the police by the federal counterterrorism focus have gone far beyond that because with that focus has come at the expense of federal activity in the violent crime area. Some federal enforcement activity has continued, particularly when it comes to bringing gun cases. For these, ATF's involvement in the President's Project Safe Neighborhood will doubtless continue at a high level, now that the agency has been transferred to the Justice Department, whose leader has long championed maximal federal effort on this front. ${ }^{87}$ But elsewhere, there has been a clear drop-off in federal deployment. As a Wall Street Journal report put it: “Already hard pressed by a shaky economy and budget cuts, police departments across the country must fill the void left by the reassigned FBI agents, investigating more bank robberies, violent crimes, and other big cases." 88 Perhaps some FBI field offices have been "reluctant to pull out of drug and gang investigations because they fear losing contacts with local agencies.”89 But the shift in federal priorities has taken a severe toll on the commitment of federal enforcement resources to violent crime and narcotics investigations. In mid-June 2003, a

\footnotetext{
${ }^{86}$ Statement of Gordon Quan on behalf of Nat'l League of Cities, House Jud. Comm., Immigration Subcomm., Oct. 1, 2003, available at http://www.house.gov/judiciary/quan100103.htm. Interestingly, no local police official testified at this hearing.

${ }^{87}$ See Press Release, Attorney General Announces Record Increase in Gun Prosecutions, New Resources to Prevent and Prosecute Gun Violence, Feb. 7, 2003, available at http://www.psn.gov/News.asp?FormMode=Release\&Lang=1; Statement of Patrick J. Fitzgerald, Concerning Combating Gang Violence, Sen. Jud. Comm., Sept. 17, 2003 (noting federal efforts to target gang violence); States of Asst. FBI Dir.Grant D. Ashley, Sen. Jud. Comm., Sept. 17, 2003; (ADD COLLOQUY WHEN AVAILABLE); see also Richman, Project Exile at 396 (noting Attorney General Ashcroft's longstanding support for federal gun enforcement projects directed against violent or predicate offenders); Homeland Security Act of 2002, Pub. L. No. 107-296, §§1111-1113 (transferring ATF from Treasury to Justice Department).

${ }^{88}$ Gary Fields \& John R. Wilke, FBI’s New Focus Places Big Burden on Local Police, Wall St. J., June 30, 2003, at 1; Laura Sullivan \& Gail Gibson, DiBiagio’s FBI Letter Draws Ire of Agents; U.S. Attorney’s Criticism Is Assailed in Light of Bureau's Terror Emphasis, Baltimore Sun, Feb. 14, 2003, B1 ("Across the country, such investigations have fallen increasingly to state and local law enforcement. Police chiefs have instructed their officers to take over local bank robberies and nonterror, intelligence-gathering operations that previously fell to the FBI.”).

${ }^{89}$ Murphy \& Plotkin, supra note _ , at 43.
} 
GAO report found that FBI field agent non-supervisory positions charged and allocated to investigating violent crime matters had gone down from 2000 in fiscal 2001 to 1000 in fiscal 2003 (and even lower during Iraqi war). ${ }^{90}$ The number of FBI agents assigned to drug cases had also gone way done, and it was not clear whether the Drug Enforcement Administration would be filling the gap. The report noted: "The overall reduction in combined FBI and DEA staffing of drug enforcement positions and the change in strategy removes some drug enforcement assistance from local jurisdictions at a time when many, if not most, state and local budgets are under intense pressure."91

Note that the point here is not that the shift in federal resources was a mistake. Indeed, as I've said elsewhere, I believe that one of the greatest benefits flowing from the federal enforcement bureaucracy's relative lack of political accountability is its flexibility in responding to changing circumstances. ${ }^{92}$ And, although the system may be overreacting to September 11, it may also be underreacting. I have no idea. What I am suggesting, though, is that the duration and apparent stability of federal agencies' commitment to street crime enforcement during the 1980s and 1990s set a new baseline for local expectations of federal enforcement assistance. And these expectations now are not being met.

A similar desire to refrain from sweeping normative judgments must also accompany my assessment of intergovernmental relations on the fiscal front. The economic downturn and the political popularity of tax cuts have obviously placed new budget pressure on state and local governments in 2002-03. That pressure surely plays critical background role in intergovernmental relations across every policy area. But the appropriate level of government at which taxes should be raised and spent -- and how high those taxes should be -- are not matters to which I bring any particular expertise. ${ }^{93}$ In the fiscal area, too, my focus is not on what is the right policy but on policy expectations, and specifically on how the creation of local grievances is likely to affect the law enforcement dynamic.

\footnotetext{
90 Statement of David M. Walker, Comp. Gen., FBI Reorganization: Progress Made in Efforts to Transform, but Major Challenges Continue, Subcomm. On Commerce, Justice, State, and the Judiciary, House Approp. Comm., June 18, 2003 (AO-03-759T), at 35.

91 Id. at 19-20; see also 2002 Annual Meeting, US Conf of Mayors, Resolution: FBI Reorganization (June 14-18) (noting that"the nation's mayor's and police chiefs are also concerned about continuing issues relating to traditional crime, particularly drug-related crime, much of which originates out of city and U.S. borders," and asking "that the U.S. Department of Justice and FBI engage in detailed and structured conversation with the U.S. Conf of Mayors to understand what the new structure of the FBI will mean for the critical war against terrorism, as well as traditional law enforcement and crime fighting in this nation.”), available at http://www.usmayors.org/uscm/resolutions/70th_conference/csj_05.asp

${ }^{92}$ See Richman, Project Exile, supra note _.

93 See Richard A. Musgrave, Devolution, Grants, and Fiscal Competition, 11 J. Econ. Perspectives 65 (1997); Roger H. Gordon, An Optimal Taxation Approach to Fiscal Federalism, 98 Q. J. Econ. 567 (1983).
} 
The new sensitivity to the terrorist threat has required massive expenditures at the state and local levels. ${ }^{94}$ How much of these expenses should be borne by the federal government has been very much a subject of political debate in 2003, with even Homeland Security Secretary Ridge conceding that initial plans to elevate interstateequity above more fine-grained assessments of need ought to be revisited. ${ }^{95}$ In the meantime, though, state and local governments have been forced to choose between spending more when the federal Homeland Security color code moves up or holding steady, relying on their own risk assessment, and assuming the risk of being wrong. To the extent that officials have responded to federal signals, the color codes have thus become a species of unfunded mandate. ${ }^{96}$ There may be an emerging trend of officials who follow independent courses, but that will have its own cost to the federal government when it comes to security coordination. ${ }^{97}$

If one source of intergovernmental tension is the overall level of federal homeland security funding, another (perhaps even more disruptive) source of tension is the way federal funds will be distributed. One police chief complained in a Spring 2003 congressional hearing that homeland security

\footnotetext{
${ }^{94}$ See Testimony of GAO Managing Director Paul L. Posner before the Subcomm. On Terrorism, Technology and Homeland Security, Sen. Jud. Comm., Sept. 3, 2003, at 15 (GAO-03-1146T) [hereinafter "Posner Testimony"] ("many local jurisdictions have taken it upon themselves to take the initiative to dramatically increase their own-source funding in an effort to enhance security"); see also Manuel Trajtenberg (Tel Aviv Univ. \& NBER), Crafting Defense R \& D Policy in the Anti-Terrorist Era (May 2003), at 18 : (strategy of "deploying resources to protect likely targets in the homeland" "makes the provision of defense mostly a local public good, even conveying negative externalities.”). http://www.nber.org/books/innovation4/trajtenberg5-8-03.pdf
}

\footnotetext{
${ }^{95}$ See Jeff Stein et al., CQ Outlook: Is Homeland Security Keeping America Safe?, CQ Weekly, June 14, 2003, at 1476 ("Ridge and many in Congress would like to tweak the [funding] formula so that while a state minimum would remain in place, the department could direct the rest by using criteria shuch as the likelihood that an area would be attacked and whether it had vulnerable sites such as nuclear or chemical plants nearby.”); see also Posner Testimony, supra note _, at 14 (comparing allocation formulae of various homeland security grant programs).

${ }^{96}$ See Century Foundation, Dennis L. Dresang, Strengthening Federal-State Relationships to Prevent and Respond to Terrorism: Wisconsin, at 24 (2003) ("The seemingly random way in which the fed got has changed the level of alert status has damaged the credibility and effectiveness of these message. Wisconsin officials feel they have no choice but to respond and activate either their procedures or their sense of vigilance.”); Century Foundation: Louise K. Comfort, Assessment of Homeland Security Initiatives: Commonwealth of Pennsylvania, at 19 (2003)"federally announced emergency alerts have required the deployment of emergency response personnel to protect critical facilities": "have placed significant burdens on county and municipal jurisdictions, which are also coping with major budget deficits."); Press Release, National League of Cities, Most Cities Reacted to Orange Alert with Higher Concern But 40\% Reported No Change, Feb. 27, 2003, .(29\% say "more guidance from the federal government is needed.)"available at www.nlc.org/nlc/_org/site/newsroom/nations_cities_weekly/
}

${ }^{97}$ Judy Nichols, Arizona May Ignore Next Orange Alert, Arizona Republic, June 1, 2003, at _ (noting "incredible problems" creating by the changing fed alert levels, "overtime, financial, functional," Arizona homeland security director says that Arizona may not follow federal moves in future, particularly where based on threats specific to other parts of country.) 
resources do not go directly to local police departments. They cannot be used to hire new police. They cannot be used to pay overtime expenses that we incur each and every time Secretary Ridge changes the alert level. They can be used to purchase equipment, but not by me. I have to wait for a statewide plan to be developed and then I have to hope that a fair share of those funds will filter to my department. $^{98}$

As a mayor put it in another hearing at around the same time: "After all, a 9-1-1 call does not get a state trooper."99 The U.S. Conference of Mayors has (unsurprisingly) expressed similar sentiments: "[W]e strongly believe that a majority of the [first responders] funding must be provided directly to cities and counties to avoid delays and ensure that our nation's front-line troops - which are predominately at the local level have immediate access to flexible resources." ${ }^{100}$ And members have suggested that partisan politics help explain the Republican administration's reluctance to give money directly to urban areas. ${ }^{101}$

Given that local governments will eventually get much of the homeland security funding, there are arguments for funneling the money through the states, and thus encouraging statewide coordination. ${ }^{102}$ Unsurprisingly, the governors have embraced

\footnotetext{
${ }^{98}$ Hearing on Homeland Security and First Responders, Sen. Governmental Affairs Comm., Apr. 9, 2003, (FDCH Pol. Trans.) (testimony of Dover, Del., police chief Jeffrey Horvath); see also id. (testimony of Portland, Me., police chief, Michael J. Chitwood ("my experience shows that when funds go thru the state, there's a bureaucratic nightmare that's created, that those resources don't get to the most neediest or to the people who need it right away.”)

${ }^{99}$ Hearing: Homeland Security: Assessing the Needs of Local Law Enforcement, Sen. Jud. Comm., Mar. 21, 2002, FDCH Cong. Test. (testimony of Mayor Patrick Henry Hays. North Little Rock, Ark., on behalf of U.S. Conf of Mayors).

100 Ed Somers, US Conf of Mayors, Mayors, Police and Fire Leaders United on Direct First Responder Funding, Letter to Congress from Conf of Mayors, et al, Jan 13, 2003, available at http://www.usmayors.org/uscm/us_mayor_newspaper/documents/01_13_03/first responder.asp; see also Philip Shenon, Counterterror Aid Is Tied Up by the States, Mayors Assert, N.Y. Times, September 18, 2003, at _; AP, Mayors Seek More Homeland Security Aid; States Are Keeping Too Much of the Money, City Leaders Tell Federal Officials, Wash. Post, June 9, 2003, at A6;Larry Copeland, Mayors Want Security Money Sent Straight to Cities, Not Statehouses, USA Today, June 8, 2003 (from Denver US Conf of Mayors meeting) ("The mayors say federal money for training, equipment and stepped-up patrols should go directly to cities, which would respond first to a terrorist attack. The money now goes to governors for distribution - a process many mayors say allows decisions to be made on the basis of state politics instead of need.”); U.S. Conf. of Mayors, One Year Later: A Status Report on the Federal-Local Partnership on Homeland Security, Sept. 9, 2002, available at http://www.usmayors.org/uscm/us mayor newspaper/documents/09_19_02/status report.asp ("To date, no significant financial assistance has been provided directly to cities across the country for this new domestic war on terrorism." Mayors have called for "creation of a new flexible Homeland Security Block Grant to be used for additional planning, training, equipment, and officer deployment through the use of overtime").

${ }^{101}$ Mike McPhee \& Gwen Florio, Security Atop Mayors’ Agenda at Denver Event, Denver Post, June 6, 2003, at _ ("City officials say they are having a tougher time getting federal dollars because the Republican administration tends to favor governors over mayors.”).

${ }^{102}$ See Larry Copeland, Mayors Want Security Money Sent Straight to Cities, Not Statehouses, USA Today, June 8, 2003 (from Denver US Conf of Mayors meeting) (Homeland Security official reminds
} 
these arguments. Speaking for the National Governors Association at a Spring 2003 congressional hearing, Massachusetts governor Mitt Romney testified: "[W]e believe it critical that homeland security funding and resources be applied against comprehensive and integrated statewide plans." "[T]he most critical step to maximizing our resources is developing integrated statewide plans and channeling virtually all homeland security funding thru these plans." "Without statewide coordination, there is no check on gaps in coverage, incompatible equipment and communications systems, and wasteful duplication."103 Less interested parties have made similar arguments. ${ }^{104}$ And, indeed, recent years have seen some states endeavoring to be not just funding brokers but informational intermediaries - doing more in the way of intelligence collection and dissemination and counterterrorism training. ${ }^{105}$

attendess "that Congress recently ordered that at least $80 \%$ of homeland security funds go to cities and counties, with states limited to 20\%" and urges "mayors to take a regional approach in applying for federal aid so neighboring cities and counties won't be vying for the same dollars.”); see also Memo, from J. Thomas Cochran, Exec. Dir., US Conf Mayors, Department of Homeland Security Announces Application Process for \$1.5 Billion in Grants (May 1, 2003) (explaining new funding: states required to sub-allocate at least $50 \%$ of funding to "local communities" within 45 days; no allocation yet of $\$ 700$ million designated "for use in high-density urban areas, high-threat areas, and for protection of critical infrastructure."), available at http://www.usmayors.org/executivedirector/cochran_050103.pdf.

103 Testimony of Gov. Mitt Romney before the Senate Gov. Affairs Comm. On Investing in Homeland Security: Challenges Facing State and Local Governments, May 15, 2003, available at http://www.nga.org/nga/legislativeUpdate/1,1169,C_TESTIMONY^D_5449,00.html; see also Testimony of Mich. Gov. John Engler (et al), before Senate Approp Comm. on Homeland Security Funding, Apr. 10, 2002 ("We want to emphasize how critical it is that federal homeland security funds be funneled through the Gov or a designated state agency. The ability to coordinate thru a single agency or office is crucial if we are to address the complexity of directing and coordinating resources towards protecting our citizens."), available at http://www.nga.org/nga/legislativeUpdate/1,1169,C_TESTIMONY^D_3579,00.html.

${ }^{104}$ See Donald F. Kettl, The Century Foundation's Homeland Security Project, Working Group on Federalism Challenges: The States and Homeland Security: Building the Missing Link (2003) ("If there is to be better coordination, it will have to be secured by the states, within a national plan. That argues for an incentive-based block-grant system, in which "the federal govt sets minimum nationwide guidelines and appropriates the necessary funding; the states receive the block grants and devise statewide plans to enhance coordination [; and local govts maintain substantial discretion about how best to build and deploy their resources, consistent with the state’s strategy.” (14).

${ }^{105}$ For information on the New York State Counter Terrorism Network, see http://www.state.ny.us/security/countert.html; see also Robert O’Harrow, U.S. Backs Florida’s New Counterterrorism Database, Wash. Post, Aug. 6, 2003, at _; California Anti-Terrorism Information Center: William Overend, War Room's Eyes Out for Terror; Safety: Data Center Links the Intelligence Gathering of Police Agencies Statewide, LA Times, Sept. 10, 2002, Part 2, p. 1; Brendan Lyons, Plan Enlists Street Cops to Fight War on Terror; Albany Law Enforcement Invited to Summit on Training, State, Local Officers to Spot Terrorism Suspects, Times Union (Albany NY), July 25, 2002, B1 (reporting summit to unveil "state's plan for formally enlisting 70,000 local cops as makeshift counterterrorism agents," but noting that "attendees said a timeline or detailed plan for the program was never outlined during the daylong, closed-door session.”); GAO, Homeland Security: Efforts to Improve Information Sharing Need to Be Strengthened, supra note _ , at 39 (noting state intelligence sharing initiatives).

Note that efforts to establish statewide criminal intelligence systems pre-date the recent homeland security focus. See http://www.iir.com/Publications/SISMonograph.pdf. 
Because they see cities as bearing the brunt (in both fiscal and political costs) of any nationwide intelligence gathering and security patrolling effort, local officials, particularly from bigger cities, would likely have complained about the very nature of Bush Administration's substantial embrace ${ }^{106}$ of the statewide funding model for homeland security. Their sense of grievance has been intensified, however, by their perception that it is "their" violent crime money that is now going to the states.

The fungibility of money makes the link impossible to prove. And, in the Bush Administration's defense, it should be noted that the COPS program has always been a Republican target. Yet urban officials have made much of the coincidence that the COPS program is being phased out, and other crime control grants reduced, ${ }^{107}$ just as homeland security funding plans are being made. As one police chief recently testified: "[T]here is a concern in the law enforcement community, that new assistance programs are being funded at the expense of traditional law enforcement assistance programs such as the COPS program, the Local Law Enforcement Block Grant Program and the Byrne Grant program."108 And as a mayor testifying last year on behalf of the Conference of Mayors put it, when complaining of plans to cut COPS by $80 \%$ and transfer other monies into the state-controlled Byrne grant program: "We must ensure that cities have the resources needed to fight both the domestic war on terrorism and the continuing war against crime. We cannot simply 'Rob Peter to Pay Paul.,’109

As I write this (October 2003), the fiscal picture is still in flux (as it probably will be for some time), with the budget wars (shocking to say) a perfect vehicle for partisan agendas. ${ }^{110}$ Congressional Democrats have been championing the cause of urban police departments for more COPS money, and the cause of "first responders" more generally

\footnotetext{
${ }^{106}$ But see Hearing on State and Local Homeland Security Challenges, Sen. Governmental Affairs Comm., May 1, 2003, FDCH Pol. Trans., at 13 (testimony of Secretary Ridge noting: "The need to separate out funds for high-threat urban areas was first recognized and addressed in the fiscal year 2003 omnibus bill. That need was again addressed in the 2003 wartime supplemental.”).

${ }^{107}$ For account of current funding plans, see 2003 proposed budget: http://www.justice.gov/jmd/2003summary/pdf/SNL-sum.pdf

${ }^{108}$ Hearing on Homeland Security and First Responders, Sen. Governmental Affairs Comm., Apr. 9, 2003, FDCH Pol. Trans. (testimony of Dover, Del., police chief Jeffrey Horvath).

109 Hearing: Homeland Security: Assessing the Needs of Local Law Enforcement, Sen. Jud. Comm., Mar. 21, 2002, FDCH Cong. (testimony of Mayor Patrick Henry Hays. North Little Rock, Ark., on behalf of U.S. Conf of Mayors); see also U.S. Conf. of Mayors, One Year Later: A Status Report on the FederalLocal Partnership on Homeland Security, Sept. 9, 2002 ("The administration is proposing to cut funding for existing law enforcement programs such as the COPS program (80 percent cut) and the Local Law Enforcement Block Grant (merged and cut 20 percent). If approved by Congress, these cuts would result in a major reduction in the ability of mayors and the police to prevent and respond to both traditional street crime and the new threat of terrorism.”), available at http://www.usmayors.org/uscm/us_mayor_newspaper/documents/09_19_02/status_report.asp

${ }^{110}$ Compare Benjamin Wallace-Wells, Bush’s War on Cops, Wash. Monthly, Sept. 2003, at _ (suggesting that virtual elimination of COPS program is leading to crime rise), with Jack Dunphy, Is Bush Anti-Cop, Nat'l Rev. Online, Oct. 1, 2003 (suggesting that COPS program is an unconstitutional waste of taxpayer dollars), available at http://www.nationalreview.com/dunphy/dunphy200310010903.asp.
} 
(i.e. localities) a larger and more directly funded share of homeland security money. ${ }^{111}$ And the localities themselves are asserting their own pressing needs. ${ }^{112}$ For its part, the Bush Administration is planning to reduce COPS funding from 1.4 billion to 164 million (80\% reduction), and to eliminate Byrne and LLEBG grants. Under the Homeland Security Appropriations Bill, signed the President on October 1, 2003, \$1.7 billion in "first responder" funding to state and local governments is being distributed by DHS's Office of Domestic Preparedness to states - and, through them, to localities -- under a formula-based grant program. The department has been allocated an additional \$725 million for discretionary grants (again to go through states) for "high-threat, high-density urban areas."113

\section{Where Next?}

Regardless of the financial and political costs of intensive counterterrorist intelligence programs, some cities can be counted to support federal efforts. Especially cities that have bourn the brunt of what may have been insufficient federal efforts in the past, and that see themselves high on the list of potential targets in the future. Even without what it (and most observers) would call "adequate" federal reimbursement, New York City has been quick to deploy its resources to the fullest, in a massive counterterrorist program. The program certainly includes large-scale and widespread security measures aimed at protecting the city's most conspicuous targets. But even more significant is the degree to which the City's police department has extended its intelligence collection activities. ${ }^{114}$ To be sure, there seems to be a degree of conscious provocation in the profile that Commissioner Kelly has given to these activities - a gauntlet challenging the feds to match the City's efforts. Yet the available evidence

\footnotetext{
111 See Helen Dewar, Senate Rejects Bid to Boost Homeland Security Funding, Wash. Post, July 23, 2003, at A7; see also various congressional websites: Levin 2003 statement, available at http://levin.senate.gov/floor/051503cs1.htm; Sen. Hillary Clinton, available at http://clinton.senate.gov/news/2003/02/2003203B53.html; Rep Meehan (D. Mass. ?) http://www.hillnews.com/news/060403/ss_cops.aspx

112 See Philip Shenon, Counterterror Aid Is Tied Up by the States, Mayors Assert, N.Y. Times, September 18, 2003, at _; Report of the Independent Task Force on Emergency Responders, Sponsored by the Council on Foreign Relations: Drastically Underfunded, Drastically Unprepared, June ?, 2003, at 2 ("uncorrected proofs") ("According to data provided to the Task Force by emergency responder professional associations and leading emergency response officials from around the country, America will fall approx $\$ 98.4$ billion short of meeting critical emergency response needs over the next 5 yrs if current funding levels are maintained.”). available at http://www.cfr.org/pdf/Responders_TF.pdf.

${ }^{113}$ See Dep’t of Homeland Security, FY2004 Budget Fact Sheet, Oct. 1, 2003.

${ }^{114}$ See Al Baker, Leader Sees New York Police in Vanguard of Terror Fights, N.Y. Times, Sept 7, 2002, at A1; William K. Rashbaum, Terror Makes All the World a Beat for New York Police, N.Y. Times, July 15, 2002, at B3; Craig Horowitz, The NYPD's War on Terror, NY Magazine, Feb. 3, 2003 ("What Kelly has done with Libutti and Cohen, essentially, is to create his own FBI and CIA within the NYCPD. 'This is all about Ray Kelly's contempt for the Feds and how they blew it, over and over again,' says a former member of the NYPD who knows the commissioner well.”).
} 
suggests that these efforts have been well coordinated with federal agencies and have enhanced federal capabilities. ${ }^{115}$

What about other cities - particularly a city like Detroit, which will be losing its COPS money and federal enforcement assistance against violent crime, does not rank at the top of the list of potential terrorist targets, and has a large Middle East immigrant population that is both a potential source of intelligence information and of political backlash to aggressive federal counterterrorist tactics?

There are many possible endings to this story. But I focus on two stylized endings, one pessimistic; the other optimistic. The first presages an increasing rift between local and federal enforcers, as the inherent collective action problem posed by any nationwide counterterrorism effort is compounded by the use of tactics perceived as over-aggressive in many communities and by local grievances arising out of dashed hopes for continuing federal support against violent crime. It is of course possible that federal enforcers will, over time, do a better job of reaching out to communities on their own. Such efforts are indeed in progress. ${ }^{116}$ Nonetheless, the relative narrowness of federal enforcement concerns and the (related) comparative distance of federal agencies from the lives of people in densely populated urban communities would likely make a federally centered intelligence gathering effort a poor substitute for a more integrated national network.

\footnotetext{
${ }^{115}$ See Remarks prepared for delivery by FBI Dir. Robert S. Mueller, III, at Citizen’s Crime Comm'n of New York, Dec. 19, 2002 (calling NYPD’s Counterterrorism Division and the its "newly revamped Intelligence Division" "models for the nation"), available at http://www.fbi.gov/pressrel/speeches/milsteinlecture.htm. But see GAO Report, Homeland Security: Efforts to Improve Information Sharing Need to Be Strengthened, supra note _, at 14 ("Officials from the Central Intelligence Agency acknowledge that states' and cities' efforts to create their own [intelligence] centers are resulting in duplication and that some cities may be reaching out to foreign intelligence sources independently from the federal government. These officials emphasized that state and local authorities should work through the Joint Terrorism Task Forces to receive the information they require.”).

Note that under draft Domestic Security Enhancement Act of 2003: DOJ would support communities in terminating state law enforcement consent decrees from before 9/11 (except where related to racial profiling). Cites

${ }^{116}$ Letter \& Report of Jamie E. Brown, AAG Leg Affairs, to Hon. F. James Sensenbrenner, Jr., Chrm., House Jud. Comm., May 13, 2003, at 56 (responding to Committee inquiries concerning USA Patriot Act implementation and related matter) (noting of Muslim populations: "If the FBI is to perform effectively its primary mission of detecting and preventing acts of terrorism, our field offices need to reach out to the overwhelmingly law-abiding and patriotic members of these communities to help us locate terrorists and supports who may reside among them in an effort to avoid detection." "[T]he FBI has reached out to these communities to assure them that, despite the emphasis on counterterrorism, investigating civil rights remains a high priority of the FBI." Over 500 meetings with Muslim leaders since 9/11 "for the purpose of establishing a dialogue and discussing procedures for alerting the local FBI office to such issues.”). available at http://www.house.gov/judiciary/patriotlet051303.pdf. Special outreach efforts to Muslim communities have also been made by the Justice Department's Office of the Inspector General, see Office of the Inspector General, Report to Congress on Implementation of Section 1001 of the USA Patriot Act (July 17, 2003), available at http://www.usdoj.gov/oig/special/03-07/final.pdf, and the Civil Rights Division’ s Initiative to Combat Post-9/11 Discriminatory Backlash. See Civil Rights Division, Enforcement and Outreach Following the September 11 Attacks (July 30, 2002), available at http://www.usdoj.gov/crt/legalinfo/discrimupdate.htm.
} 
Those looking for more evidence of the fraught nature of federal information gathering initiatives need only to follow the TIPS (Terrorist Information and Prevention System) debacle. First mentioned by President Bush in his 2002 State of the Union Speech, the program was pitched by the Justice Department as a way to enlist the observatory powers of service providers around the nation in the War on Terror. Before long, under pressure by many in Congress and elsewhere, the program was reconfigured to "involve only truckers, dock workers, bus drivers and others who are in positions to monitor places and events that are obviously public."117 Even that was not enough, and the initiative was soon legislated out of existence. ${ }^{118}$

There is a far more optimistic ending, though. The fiscal and operational pressures on federal resources may preclude either the resuscitation of the violent-crime model of intergovernmental interaction or the outright enlistment ${ }^{119}$ of state and local governments in a federally directed counterterrorism campaign. But in place of the violent-crime model will emerge a counterterrorism-based model that courts state and local assistance by giving them a greater voice in how the federal government interacts with citizens, and particularly with immigrant communities.

Secrecy obviously has its place in any counterterrorist program. And if every tip and the planning of how it is to be followed up have to be shared with enforcers and agencies across the nation and at every level of government, operational effectiveness will surely be reduced (if not completely precluded). Institutional considerations reinforce operational considerations on this point. If we want to tear down the "wall" that has hampered cooperation between the FBI and the rest of the intelligence community (especially the CIA) in the past, we will have to create a federal domain of very closely held information to ensure that actual or alleged security considerations don't become excuses for information hoarding.

But how can the feds make sure the tips come in to begin with? This is where the informational networks that only state and local enforcers have access to come in. And the "price" of their participation will be a voice in federal policy-making and execution that, in the long run, will give those processes a new degree of accountability.

\footnotetext{
${ }^{117}$ Dan Eggen, Under Fire, Justice Shrinks TIPS Program, Wash. Post, Aug. 10, 2002, at A1; see also Oversight of DOJ, Hearing of the Sen Jud Comm, July 25, 2002, Federal News Service, at 9 (testimony by AG Ashcroft) ("TIPS program is something requested by industry to allow them to talk about anomalies that they encounter, but it does not refer to a program related to private places by homes.”).

${ }^{118}$ See Dan Eggen, Proposal to Enlist Citizen Spies Was Doomed From Start, Wash. Post, Nov. 24, 2002, at A11 (Justice Department's “the retreat did little to calm lawmakers' fears, leading to language in the final version of the Homeland Security package prohibiting 'any and all activities' to implement the program"; Department spokesperson says that TIPS “'was never operational, so there's nothing to shut down."”).

${ }^{119}$ Cf. David Williams, The Bureau of Investigation and Its Critics, 1919-1921: The Origins of Federal Political Surveillance, 68 J. Am. Hist. 560, 561 (1981) (“On Friday night, Jan. 2, 1920, agents of the BI with the aid of local police arrested 10,000 'members' of the Communist and Communist Labor parties in simultaneous raids throughout the country.").
} 
However important it is for the Federal Government to move into the terrorism prevention business, that line of work has historically posed peculiar risks to democratic society. Domestic intelligence operations lack the outcome measures of regular law enforcement, have extremely low visibility because of security sensitivities, and often involve political or potentially political judgments. The more committed an agency is to these operations, the greater its need for political cover from the White House, which has often been tempted to extract intelligence targeting power in return, and to use that power for inappropriate political ends. This dynamic helps explain why the FBI - though traditionally ready to provide political intelligence to Presidents ${ }^{120}$---- was able to resist the pressure from Lyndon Johnson to connect antiwar protests to foreign subversion, and the CIA was not. ${ }^{121}$ In the community policing literature, those who argue for greater sensitivity to community preferences have to confront questions of who represents the community, and whether the community has been adequately organized to convey its preferences. ${ }^{122}$ When one scales up the model to the national level, however, this may be less of an issue, as there already are institutional structures -- cities, towns, counties that can legitimately speak to local concerns and, while doing so, promote the gathering of local information. Precisely how the federal interest in a national intelligence network can be squared with demands for accountability (and consequent sensitivity) at the local level is something that government officials in cities like Portland, Oregon, and Boise, Idaho, have struggled to work out. In both cities, federal regulations restricting access to intelligence information clashed with civilian oversight mechanisms. ${ }^{123}$ The contours of

${ }^{120}$ CHECK: See Church Comm Report: "The FBI practice of supplying political information to the White House and, on occasion, responding to White House requests for such information was established before 1964. However, under the administrations of President Lyndon Johnson and Richard Nixon, this practice grew to unprecedented dimensions."

See Church comm. report: http://www.icdc.com/ paulwolf/cointelpro/churchfinalreportIIb.htm (TAN 567); See Part E “Political Abuse of Intelligence Information,” available at http://www.icdc.com/ paulwolf/cointelpro/churchfinalreportIIce.htm:

--see sub-finding c: "The FBI has also volunteered information to Presidents and their staffs, without having been asked for it, sometimes apparently to curry favor with the current administration.”

${ }^{121}$ See Church Comm Report: CIA develops CHAOS in response to LBJ/WH pressure (TAN 450). Push for info connecting dissidents to foreign control, despite knowledge of illegality of CIA activity (TAN 463). For account of how FBI's refusal to aggressively pursue alleged link between antiwar protests and foreign subversion led LBJ to seek assistance from CIA, see Mark Riebling, Wedge: From Pearl Harbor to 9/11: How the Secret War Between the FBI and CIA and Endangered National Security, 263 (2002 ed.).

${ }^{122}$ See Robert Weisberg, Norms and Criminal Law, and the Norms of Criminal Law Scholarship, $93 \mathrm{~J}$. Crim. L. \& Criminology 467, 517 (2003); Tracey L. Meares, Praying for Community Policing, 90 Calif,. L. Rev. 1593 (2002); Dan M. Kahan \& Tracey L. Meares, The Coming Crisis of Criminal Procedure, 86 Geo. L.J. 1153, 1182-83 (1998).

123 See Maxine Bernstein, Police Anti-Terror Role Studied, The Oregonian, Sept. 17, 2002, at B1 (noting concern of Portland City Council members that "While the city audits its cops on local intelligence cases, it has no jurisdiction, outside the police chief, to review their work with federal authorities.”). In Boise, the Community Ombudsman sought access to files created by new police Criminal Intelligence Unit under a city ordinance giving him access to all police files. But federal guidelines, under which the unit was set up, bar access to non-law enforcement officers. See 28 CFR Pt. 23(OJP Criminal Intelligence Systems Operating Policies), available at http://www.rocic.com/cfr.pdf. Backed by Idaho's congressional delegation and the U.S. Attorney, the city sought a waiver, but was turned down by the Justice Department, leaving the City Council with the choice of leaving demanding civilian access, and thus precluding membership in the federal intelligence network or reducing local accountability. See Patrick Orr, Council 
such local struggles will vary from place to place. But their effect on the sensitivity of federal officials to local politics - heightened when congressional representatives take up the causes of local officials ${ }^{124}$---- will be salutary.

Had the new demands on local enforcers not been accompanied by a broad shift away from the violent crime model of intergovernment relationships, would local officials have been similarly prone to push back against federal demands? As with all such counterfactuals, this one is hard to answer. Everyone, we are told, has his price, and presumably this applies to local officials being asked by federal authorities to assist in times of national need. We need not answer this question, however, to say that the shift away from the violent crime model has significantly affected these officials' readiness to question the fiscal and political costs that federal counterterrorism policies threaten to impose on them. Perhaps they will be bought off in the future with a new influx of federal money. But more likely, in this Panglossian tale, the shift in federal priorities and the effect of that shift on state and local officials -- will play a critical role in ensuring that, in their new focus on counterterrorism, federal authorities do not lose sight of the values of those they protect. Indeed, in an area where constitutional and statutory guarantees are ill-defined and where they may not cover what many would consider to be troubling government action, ${ }^{125}$ this developing dynamic may offer the best promise of appropriately tempered zeal as we move into the post-9/11 era.

Needs to Decide on Ombudsman's Access to CIU Files; Intelligence Team Needs Oversight, Critics Believe, Idaho Statesman, Apr. 20, 2003, at 1. See also Patrick Orr, Request for Crime-Record Waiver Lost; Feds' OK Needed for Ombudsman to Review Files, Idaho Statesman, Dec. 29, 2002, at 1. For more discussion, see http://www.idahomediaproject.org/ciu.html

${ }^{124}$ See GAO, Homeland Security: Efforts to Improve Information Sharing Need to be Strengthened, supra note _ , at 33 (explaining how congressional oversight role counseled solicitation of views of state and local government officials on information sharing).

125 See Samuel R. Gross \& Debra Livingston, Racial Profiling Under Attack, 102 Colum. L. Rev. 1413 (2002); William J. Stuntz, Local Policing After the Terror, 111 Yale L.J. 2137 (2002); Mariano-Flordentino Cuéllar, Choosing Anti-Terror Targets by National Origin and Race (SSRN draft), available at http://papers.ssrn.com/sol3/delivery.cfm/SSRN_ID413580_code030612570.pdf?abstractid=413580. 